\title{
Social representations of premature birth from the perspective of individuals born preterm in the 1990s
}

\author{
Prof. Pía Leavy ${ }^{a}$, Prof. Martina Violeta Prina ${ }^{b}$, María José Martínez Cáceres, M.D.c, \\ and Gabriela Bauer, M.D. ${ }^{c}$
}

\begin{abstract}
Introduction. Prematurity is a public health problem that calls to focus on its causes and consequences through a trans disciplinary approach. There are no studies analyzing premature birth from the perspective of individuals born preterm.

Objective. To identify social representations associated with premature birth of individuals born preterm in the 1990s in Argentina.

Population and Methods. Twelve focus groups were conducted with individuals born preterm with a birth weight $\leq 1500 \mathrm{~g}$ assisted at tertiary care facilities between 1990 and 1995. Focus group contents were analyzed based on the social representation theory.

Results. Fifty-nine adolescents and youth participated; their median age was $18.5 \pm 2.3$ years old. Based on the analysis of focus groups, six core themes were developed: life experience, parents' memories and experiences, overprotection, body, education, relationship with the medical practice and knowledge.

Conclusions. The methodology used allowed to create a space for mutual recognition and reflection for participants. Prematurity is a significant element, especially in those who suffered major sequelae. Adolescents and youth give a warning on the negative effects caused by overprotective parents and reveal the possibility of redefining the challenges associated with their history of premature birth.

Key words: premature birth, qualitativestudy, social representations, overprotection.
\end{abstract}

http:/ /dx.doi.org/10.5546/aap.2015.eng.6

\section{INTRODUCTION}

Prematurity is a global public health problem. ${ }^{1}$ Approaches to premature births are usually restricted to the medical perspective and, so far, have provided partial solutions. There is international consensus on the need to develop new research strategies that go beyond traditional boundaries among disciplines and encourage investigators, clinicians, social science experts and public health policy makers to work jointly on innovative and comprehensive initiatives. ${ }^{2}$

Premature birth in Argentina is the main reason for admission to neonatal intensive care units and has a significant influence on child mortality.

Long-term studies allow to come closer to neonatal care outcomes beyond survival and contribute to the health care quality assessment process, including support and information provided to families, potential coverage for special needs, and public policy planning aimed at future cohorts. ${ }^{4,5}$

As part of a medical study to assess health outcomes related to ex-preterm individuals born in the $1990 \mathrm{~s},{ }^{6}$ an anthropological perspective was included to consider the experiences and perspectives of those individuals who experienced this problem. This approach conceives social subjects as reflective actors who define the social reality in which they live. ${ }^{7}$

It is known that prematurity involves relationships among different subjects who ascribe varying meanings to it and experience it from different perspectives. We found studies that included the perspective of parents, health care professionals and family

Funding:

Fundación Garrahan, Oñativia Scholarship and Unicef.

Colaborators: Patricia Fernández ,M.D., Rossana Scoccola,M.D., Teresa Sepúlveda,M.D., Fernanda Burascci,M.D., Clara Gilli, BSc., Diana Rodríguez,M.D., Vilma Oreiro,M.D., Liliana Saglio,M.D., Norma Aspres,M.D. and Victoria Binda,M.D. 
members, but none taking into account the perspective on this issue of those who were born preterm. ${ }^{8-10}$ The objective of this study is to analyze social representations of premature birth of adolescents and youth born preterm.

\section{POPULATION AND METHODS}

Design: descriptive, cross-sectional and qualitative study.

Population: individuals included in a long-term medical study, born preterm between 1990 and 1995 , with a birth weight $\leq 1500 \mathrm{~g}$ and hospitalized at the neonatal intensive care units of the following hospitals: J. Fernández, J. P. Garrahan, Italiano de Buenos Aires, A. Posadas, Materno Infantil Ramón Sardá, Hospital de Clínicas J. de San Martín, C. Durand. Adolescents and youth were contacted and invited to participate in the study using the data from historical databases of each of the participating hospitals. Invitations were sent by mail or made on the telephone, social networks and/or people internet search engines. ${ }^{11}$ Their participation in the study depended on their goodwill and willingness. The only restriction for not inviting subjects was if they had severe cognitive impairment.

Data collection: the methodology applied was that of focus groups (FG). The needed number of FG was estimated to be, at least, 10, with a minimum of three and a maximum of twelve participants each. FG were conducted in the classroom of the teaching ward of Hospital Juan P. Garrahan. The objective was to get as many participants and perspectives as possible, until reaching discourse saturation. ${ }^{12,13}$ Social representations of premature birth were addressed in association with different life stages (birth, childhood, education, and the present time) and subjective experience dimensions (selfrepresentation, family relationship, and medical practice). Resources: questions about memories on birth as recalled and told by family members, and childhood and education memories; snapshots of places, babies, trades and professions, hospitals, leisure activities (games, sports, art, etc.); reading quotes from research on premature birth; individual writing assignment based on the following topic: "The meaning of having been born preterm."

Data analysis: FG were recorded and transcribed to a document. Data were coded by classifying and grouping social representations of premature birth into a matrix of categorical analysis considering criteria of salience, significance and connection. ${ }^{14}$ Based on this and on scientific bibliography on this field, predefined themes were recreated and six core themes were developed. The approach used for analysis was the theory of social representation, which is part of the epistemological guidelines established by symbolic interactionism. According to this, social representations are defined as "a form of socially elaborated and shared practical knowledge," which vary "according to the position of subjects in their social structure, their associated interests and perception schemes acquired through social world experience."15-17

This study was approved by the ethics committees of participating hospitals. Informed consents or assents were obtained according to participants' age.

\section{RESULTS}

Of the 135 adolescents and youth participating in the outcome assessment medical study, 22 had severe mental retardation. The rest was invited to participate in the study, and 59 accepted. They were included sequentially into 12 FG made up of 3 to 8 participants, which lasted between 60 and 100 minutes. FG were conducted in a relaxed atmosphere. Table 1 summarizes participant characteristics. Participants were predominantly girls, their average age was 18.5 years old, most were attending secondary school or had completed it, and about one third worked.

Based on the analysis, six core themes were suggested: life experience, parents' memories and experiences, overprotection, body, education, relationship with the medical practice and knowledge, all described below. Selected quotes reflect the most common representations.

\section{Life experience}

The meaning that subjects assign to having been born preterm varies according to their health status, sequelae and life experience. Those who had sequelae and special health care needs ${ }^{18}$ in their childhood associate their preterm birth to a life of efforts and difficulties: "I received lots of stimulation; otherwise, I would have ended up in a wheelchair. I also had a hard time learning to talk." To them, prematurity is a significant component of their identity construction: "To me prematurity is very special, it is like any other life but different" (FG 4). Those who did not suffer major sequelae associate premature birth only to a past event, to their hospitalization after birth, and they even believe that their identity is constructed based on 
other, more important, aspects: "To me, the fact of having been adopted is even more shocking than having been born preterm" (FG 1).

Beyond life experiences, even though most participants recognize medical efforts, they attribute their survival to a miraculous and extraordinary event. This is reflected in the choice of certain names, such as Milagros and Natanael (Miracle and Gift from God in Spanish, respectively), and their statements: "I am proud of having been born preterm. I almost passed away, and so did my mom. We both made it and it was a miracle" (FG 6).

\section{Parents' memories and experiences}

For ex-preterm subjects, prematurity is more about their parents' experience than about themselves: "When I tell my story, I use the third person; my mom went through this, not me. She considers my story her own" (FG 1). "We are based on what we were told, not on what we experienced" (FG 8). Participants also emphasize their parents' suffering and uncertainty: "Parents suffer much more than us; they had to suffer waiting for us to get better and see us in that status" (FG 1). They perceive their parents consider them to be more vulnerable and dependent on their custody than the rest of their children or their peers. This may lead to inter- and intragenerational conflicts: "I have always been treated differently than my sisters. Yes, they tend to be overprotective, that bothers me" (FG 2).

\section{Overprotection}

This is a traumatic experience for parents, and it is projected into their present relationship with their children: ${ }^{19}$ "I wanted to have a piercing but my mother would not let me because they gave me lots of pricks when I was hospitalized and I had suffered, but I do not remember it" (FG 4). When overprotection is based on giving excessive care to preterm children, the relationship between parents and children becomes distorted. In this regard, a quadriplegic adolescent stated: "All moms left, but my mother would stay all morning at school with me [...]; I started caring for myself and I had to push her away a bit so that I could lead my own life" (FG 5). Overprotective parents may cause adverse effects because they tend to resent their children's personal trust and impact on their autonomy. ${ }^{20}$

\section{Body}

Prematurity was associated to their small size at birth: "They always told me that I looked like a tiny rat, that they did not know how to hold me" (FG 12). Short stature is a common characteristic throughout their life: "I have always been second in line at school" (FG 9), even at present.

In addition, hospitalization and different interventions in their first days of life have left marks on their bodies. Such marks may become a stigma if their peers give them a negative meaning, leading to prejudice and discrimination: ${ }^{21}$ "I do not like the scar on my belly [...]; I was at the beach and everyone kept

TABLE 1. Characteristics of 59 youth participating in focus groups

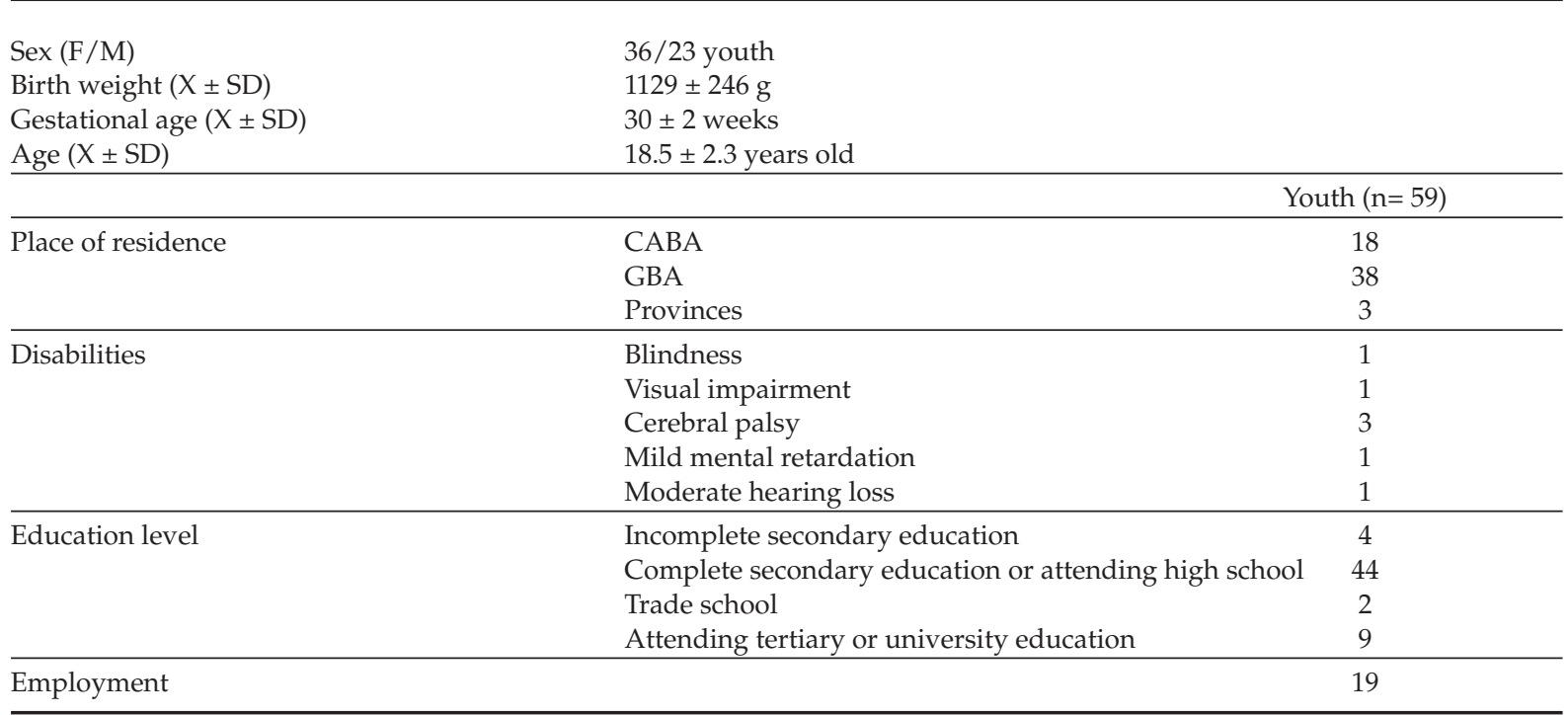

CABA: Autonomous City of Buenos Aires.

GBA: Greater Buenos Aires. 
staring at me like 'That is a big scar!'” (FG 3). Being afraid of becoming the laughingstock may make them feel insecure, thus affecting the construction of their own identity: "I think about these things (scars) when it comes to girls; it makes things more difficult because girls think you have washboard abs but your stomach is actually all flabby because of a poorly healed scar resulting from a surgery" (FG 6), said one participant in relation to a keloid resulting from a surgery.

However, some take ownership of these marks and give them a new, positive meaning: ${ }^{22}$ "When I was young, I felt embarrassed when I had to take off my t-shirt, I thought they would all stare at my scar, and I developed a body image complex. Now I have tackled this issue and it has become part of my story, thanks to this scar I am alive" (FG 9). In this case, the scar becomes the footprint of a surgery that allowed the participant to survive, and this is more significant than the stigmatizing vision of others.

\section{Education}

Difficulties in the first school years were related to the different treatment itineraries. ${ }^{23}$

Overlapping of special health care needs and school hours resulted, in some cases, in a poor school performance: "I felt left out, I was always missing school because I had to go to the hospital for check-ups" (FG 10). Repeating a grade was frequently associated with learning difficulties and an achievement gap in relation to classmates. Several interviewees had to attend a remedial education program. Most of them felt comfortable in such setting because it helped them overcome their learning difficulties and favored their socialization: "I attend a special education school because when I was in a bilingual school I could not advance to the next grade, the other kids mocked me or left me aside, they did not understand my problem. I am doing fine now" (FG 7).

\section{Relationship with the medical practice and knowledge}

The hospital and the relationship with the medical team play a significant role, which is sometimes contradictory. On the one hand, many participants stated that they were thankful and appreciated the bonds established in the hospital setting. On the other, they often mentioned how medical diagnoses were uncertain or pessimistic regarding their survival and potential sequelae.
Some participants indicated having had a negative experience with health teams: "They said that I was not going to walk and that I was going to be blind, deaf and mute. They would give me no hope and say: 'This baby will not make it to the sixth day..." (FG 8). "My father was told that when birth is premature, either the baby or the mother dies... but here we are, both of us are alive" (FG 5). Likewise, they felt uncertain about what aspects of their present health status were actually related to their history of premature birth.

Another recurrent topic were restrictions to enter hospitalization units: "My parents say they were at the neonatal intensive care unit but they kept asking them to leave, they would tell them to go, that they could not go in" (FG 11). Pessimism regarding diagnosis and restrictions on family company may be some of the elements that worsen the trauma caused by a preterm birth.

Mixed feelings are observed in those participants who have special health care needs at the hospital, from familiarity and thankfulness to rejection and discomfort: "It is a complicated subject because I am alive thanks to the hospital, but I am tired [...]. Now I just go for scheduled check-ups, but when I am there, I just want to leave" (FG 9).

\section{DISCUSSION}

There are some studies that include the point of view of parents with preterm babies, but there is little or no evidence on the experiences reported by adolescents and youth born prematurely. ${ }^{7,9,24,25}$ It is worth noting that adolescents and youth experiences are associated with complex identity formation processes. ${ }^{11,26}$ Having been born preterm plays a more significant role in the process of those who have more special health care needs and sequelae. One of the weaknesses of the FG technique is that it was not possible to include perceptions and experiences of preterm individuals with severe cognitive impairment.

The "early and sudden detachment of the mother and the baby" as a consequence of a preterm birth and the subsequent hospitalization of the newborn infant results in a traumatic experience for mothers and family members alike. ${ }^{17,27}$ Stories herein collected reveal how the parents' traumatic experience may extend over time and have an effect on their children's upbringing and experiences. Although family support is essential for their growth and wellbeing, overprotection may turn detrimental for the development of their autonomy, decision- 
making capability and sociability. ${ }^{17}$ These findings are consistent with the vulnerable child syndrome, characterized by parents' unfounded anxiety regarding their child's health and overprotection, which has a negative impact on their bond. ${ }^{28}$ Several publications have warned on the importance of detecting this syndrome early in the population of children with a history of premature birth. ${ }^{29,30}$

Social representations related to body and education allowed us to establish that patients are capable of redefining stigmas resulting from premature birth. In this regard, one of the strengths of the methodology applied is that it created a space for dialogue and identification where participants expressed their personal anxieties, exchanged tips, questioned what was considered socially abnormal, and emphasized their own and others' strengths. ${ }^{16}$

As a hypothesis, it is suggested that the fact that they perceive their survival as a miracle is associated with the uncertainty and pessimism of medical diagnoses made while admitted to the neonatal intensive care unit. Both might be associated with low survival rates. Participants of this study were born in the early 1990s in Argentina, when approximately 2000 preterm babies with a very low birth weight survived each year, ${ }^{31}$ while in 2010, with few modifications in the number of preterm births and deliveries versus the early 1990s, approximately 5200 preterm babies with a very low birth weight survived. ${ }^{32}$ These figures evidence significant improvements in health care services. In spite of such advances, stories from 15 to 20 years ago on communication problems between medical teams and families, lack of information, and restriction on family company during hospitalization continue, to a certain extent, to these days. ${ }^{33}$ The negative perception of ex-preterm subjects in relation to these issues highlight the importance of making advancements towards overcoming such hurdles.

\section{CONCLUSIONS}

This study describes an innovative approach. On the one hand, it took into account the perspective on prematurity of adolescents and youth born preterm; on the other, it provided a space for mutual recognition and reflection for individuals who suffered this condition.

Prematurity accounted for a significant element in the construction of identity among adolescents and youth interviewed in the study, especially for those who suffered major sequelae.
Ex-preterm subjects warn on the negative effects of overprotective parents and reveal the possibility of redefining the challenges associated with their history of premature birth. In addition, representations about communication problems between families and medical teams continue to these days and should be addressed by the health care system through an interdisciplinary approach that also includes subjects' perspectives.

\section{Acknowledgments}

To all focus group participants for opening up and for their willingness to be part of this research. To Zulma Ortiz, M.D. and Carla Perrota, M.D., for their technical guidance.

\section{REFERENCES}

1. Organización Mundial de la Salud. Nacido Demasiado Pronto: Informe de Acción Global sobre Nacimientos Prematuros. Resumen Ejecutivo. Año 2012. Ginebra, 2012. Available at: http:/ / www.who.int/pmnch/media/ news/2012/borntoosoon_execsum_es.pdf. [Accesed: December 22, 2012].

2. Stevenson DK, Shaw GM, Wise PH, Norton ME, et al. Transdisciplinary translational science and the case of preterm birth. J Perinatol 2013;33(4):251-8.

3. Argentina. Ministerio de Salud de la Nación. Semana del Prematuro 2012. Buenos Aires, 2012. Available at: http: / / www.msal.gov.ar/index.php/component/content/ article/46/290-semana-del-prematuro-2012. [Accesed: March 10, 2014].

4. Behrman R, Butler AS, eds. Preterm births: causes, consequences, and prevention. Washington (DC): National Academies Press (US), 2007. Available at: http://www. ncbi.nlm.nih.gov/books/NBK11362/. [Accesed: January 22, 2014].

5. Saigal S, Rosenbaum P. What matters in the long term: reflections on the context of adult outcomes versus detailed measures in childhood. Semin Fetal Neonatal Med 2007;12(5):415-22.

6. Martínez Cáceres MJ, Fernández P, Scoccola R, Sepúlveda $\mathrm{T}$, et al. Estado de salud e inserción social en adolescentes y adultos jóvenes con historia de prematurez y muy bajo peso al nacer en Argentina [abstract]. En: IX Congreso de la Sociedad Iberoamericana de Neonatología (SIBEN); 2023 de junio de 2012; Belo Horizonte, Brasil.

7. Giddens A. Consecuencias de la Modernidad. Madrid: Alianza Universidad; 1993.Págs.22-34.

8. Botelho SM, Boery RN, Vilela AB, Santos W, et al. O cuidar materno diante do filho prematuro: um estudo das representaçoes sociais. Rev EsC Enferm USP 2012;46(4):929-34.

9. Davim RM, Enders BC, Silva RA. Mothers' feelings about breastfeeding their premature babies in a rooming-in facility. Rev Esc Enferm USP 2010;44(3):713-8.

10. De Souza NL, Pinheiro-Fernandes AC, Clara-Costa Ido C, Cruz-Enders B, et al. Domestic maternal experience with preterm newborn children. Rev Salud Pública (Bogotá) 2010;12(3):356-67.

11. Bianculli CH. Realidad y propuestas para continencia de la transición adolescente en nuestro medio. Adolesc Latinoam 1997;1(1):31-9.

12. Javorski M, Caetano LC, Vasconcelos MG, Leite AM, et 
al. As representações sociais do aleitamento materno para mães de prematuros em unidade de cuidado canguru. Rev Latinoam Enferm 2004;12(6):890-8.

13. Souza Minayo MC. La artesanía de la investigación cualitativa. Buenos Aires: Lugar Editorial; 2009. Págs. 23-34.

14. Sautu R. Estilos y prácticas de la investigación biográfica. En: Sautu R, ed. El método biográfico. La reconstrucción de la sociedad a partir de los testimonios de los actores. Buenos Aires: Editorial de Belgrano; 1999. Págs. 21-60.

15. Jodelet D. La representación social: fenómenos, concepto y teoría. En: Moscovici S, ed. Psicología Social II. Barcelona: Paidós; 1985. Págs. 469-94.

16. Blumer H. El Interaccionismo simbólico. Perspectiva y método. La posición metodológica del interaccionismo simbólico. Barcelona: Hora. 1982; Capítulo 1:1-76.

17. Bourdieu P. El sentido práctico. Objetivar la objetivación. Madrid: Taurus. 1991; Capítulo 1:51 68.

18. Newacheck PW, Strickland B, Shonkoff JP, Perrin JM, et al. An epidemiologic profile of children with special health care needs. Pediatrics 1998;102(1 Pt 1):117-23.

19. FractmanA. Elconcepto del trauma según diferentes autores psicoanalíticos. Los desarrollos acerca del trauma psíquico según Sigmund Freud. Psicoanálisis 2005;27(1/2):213-222.

20. Bautista Lozada YR. La autonomía del alumno en el aprendizaje. Reto del nuevo modelo educativo del IPN. Innovación Educativa 2005;5(25):41-54.

21. Goffman E. Estigma: la identidad deteriorada. Buenos Aires: Amorrortu; 2008. Págs. 23-5.

22. Cornish F. Challenging the stigma of sex work in India: material context and symbolic change. J Community Appl Soc Psychol 2006;16(6):462-71.

23. Csordas TJ, Kleinman A. The therapeutic process. En: Sargent CF, Johnson TM, eds. Medical anthropology: contemporary theory and method. Westport: Praeger; 1996. Págs.3-20.

24. Carvalho JB, Araújo AC, Costa IC, Brito RS, et al. Representação social de pais sobre o filho prematuro na Uni- dade de Terapia Intensiva Neonatal. Rev Bras Enferm 2009;62(5):734-8

25. Cardoso MV, Souto KC, Oliveira MM. Compreendendo a experiência de ser pai de recém- nascido prematuro internado na unidade neonatal. Rev Rene 2006;7(3):49-55.

26. Reguillo Cruz R. Emergencia de culturas juveniles. Estrategias del desencanto. Buenos Aires: Norma, 2000. Available at: http://www.oei.org.ar/edumedia/pdfs/ T03_Docu7_Emergenciadeculturasjuveniles_Cruz.pdf . [Accesed: May 22, 2014].

27. Izzedin-Bouquet R. La maternidad en la prematurez: a propósito de dos casos clínicos. Psicología Segunda Época 2009;XXVIII(1):95-106.

28. Kokotos F. The vulnerable child syndrome. Pediatr Rev 2009;30(5):193-4.

29. Teti DM, Hess CR, O'Connell M. Parental perceptions of infant vulnerability in a preterm sample: prediction from maternal adaptation to parenthood during the neonatal period. J Dev Behav Pediatr 2005;26(4):283-92.

30. Allen EC, Manuel JC, Legault C, Naughton MJ, et al. Perception of child vulnerability among mothers of former premature infants. Pediatrics 2004;113(2):267-73.

31. De Sarasqueta P. Mortalidad neonatal y posneonatal en recién nacidos de peso menor a $2500 \mathrm{~g}$ en la República Argentina (1990-1997). Arch Argent Pediatr 2001;99(1):58-61.

32. Argentina. Ministerio de Salud de la Nación. Secretaría de Políticas, Regulación e Institutos. Estadísticas Vitales. Información Básica Año 2010. Buenos Aires, 2011. Available at: http://www.deis.gov.ar/publicaciones/archivos / Serie5Nro54.pdf. [Accesed: March 12, 2014].

33. Ortiz Z, Perrotta C, Bauer G, Messina A, et al. Derechos de los recién nacidos prematuros. Derechos 1 y 2: a un control adecuado del embarazo y a nacer en un lugar adecuado. Buenos Aires: UNICEF, 2013. Available at: http:/ /www. unicef.org/argentina/spanish/GuiaDerechos1y2_web. pdf. [Accesed: March 11, 2014]. 